\section{OPEN JOURNAL SYSTEMS}

ISSN:2237-2202
Available on line at Directory of Open Access Journals

Journal of Hyperspectral Remote Sensing v.7, n.7 (2017) 408-422

www.periodicos.ufpe.br/revistas/jhrs
Journal of Hyperspectral Remote Sensing

\title{
Use of remote sensing in the identification of Urban Heat Islands and in the evaluation of Human Thermal Comfort
}

\author{
Rafaela L. Costa*, Gustavo M. M. Baptista** e Fabrício D. S. Silva*** \\ * $\mathrm{PhD}$ in Geoscience; University of Brasilia - UnB, Campus Universitario Darcy Ribeiro, Brasilia - DF, Brasil. \\ Email: rafaelalisboac@gmail.com (Corresponding author) \\ *** Adjunct Professor, Institute of Applied Geosciences, Universidade de Brasília - DF, gmbaptista@unb.br. \\ **** Adjunct Professor, Atmospheric Sciences Institute, Universidade Federal de Alagoas, Maceió-AL, fabricio.santos@icat.ufal.br
}

Received 13 June 2017; accepted 30 October 2017

\begin{abstract}
The objective of this study was to identify heat islands and to evaluate the degree of thermal comfort / discomfort in selected urban areas. Landsat 5 and 8 satellite images were use in the thermal bands and, as a complement, observed data from meteorological stations present in the chosen cities. In order to evaluate heat islands and the degree of thermal comfort / discomfort, the surface temperature was obtain and the Kawamura Discomfort Index $\left(\mathrm{ID}_{\mathrm{K}}\right)$ was use. By means of surface temperature images, it was possible to identify the heat islands in these areas. For $\mathrm{ID}_{\mathrm{K}}$, in spite of this index, in general, to present the situation of comfort, for some areas were observe situations of discomfort and heat stress due to the heat, mainly in the year of 2016, considered one of the hottest of this century. The use of observed data was necessary in order to corroborate with the information of the satellites.

Keywords: Surface temperature, Kawamura Discomfort Index, urban climate.
\end{abstract}

\section{Introduction}

The Brazilian cities follow a common tendency associated to the development of the last years: the urban expansion that is not restricted only the most populous cities. According to the United Nations, more than half of the world's population lives in urban areas, a percentage that will increase to $60 \%$ or more by 2030, and in Latin America, including Brazil, by 2030, to $83 \%$ of the population (UN, 2008). Among the uncertainties about global climate change, there is at least one certainty felt by the population: the climate of cities is changing. The population of large urban centers, mainly, has complained, over the years, that the climate is "warmer". In fact, this can be observe in large cities, due, apparently, to the accelerated process of urbanization.

The urban climate is the climate that takes place in the urban environment. It is a result of the combination of global geographic factors, such as height and longitude, and local climatic factors, such as street morphology, shape and layout of buildings, afforestation of free spaces and materials that make up the soil (Nedel, 2008).
In the urbanization process observed in large cities over the years, such as the suppression of vegetation and the replacement of green areas by asphalts and buildings, local temperatures change. This disorderly process of growth of urban areas, due to bad planning, has caused a peculiar phenomenon, known as Urban Heat Islands (Baptista, 2003). The population increase is directly related to changes in land use, factors that directly influence the local microclimate, causing impacts on the moisture balance and changes in the ecosystem (Souza and Alvalá, 2014).

The urban heat islands are characterized by the difference in temperature between surface or air temperature in an urban area and in neighboring rural or suburban areas (Arya, 2001; Freitas and Dias, 2005). The study by Lombardo (1985) is one of the pioneers in analyzing the Heat Islands, using remote sensing for the city of São Paulo from data from the NOAA satellite. Their results found differences of up to $10^{\circ} \mathrm{C}$ between the metropolitan area and the neighborhood. The availability of sensor data obtained from orbital platforms allowed the advancement of the use of remote sensing for studies applied to the Islands of 
Heat (Tomlinson et al., 2011; Freitas et al., 2011; Peng et al., 2012).

An Island of Heat develops, most of the time, when the winds are weak. Under these conditions, in some large metropolitan areas, relative heating of the city, compared to its surroundings, can promote convective air circulation: relatively warm air rises above the center of the city and is replaced by colder and denser air converging in the rural areas. The ascending air column accumulates aerosols over the city forming a cloud of dust, that is, pollutants, which can become more often concentrated in an urban area than in rural areas (Freitas, 2003).
The difference between urban and rural air temperatures, also known as heat island strength or intensity, is commonly used to measure its effect. This intensity varies throughout the day and at night. In the morning, the temperature difference between these two areas is generally lower. Throughout the day, these differences increase as the air over the cities warms. The island of heat is usually more intense at night as urban surfaces continue to release heat and decrease cooling during nighttime. Figure 1 shows, in a general way, the profile of the temperature behavior in urban and rural areas, evidencing the islands of heat.

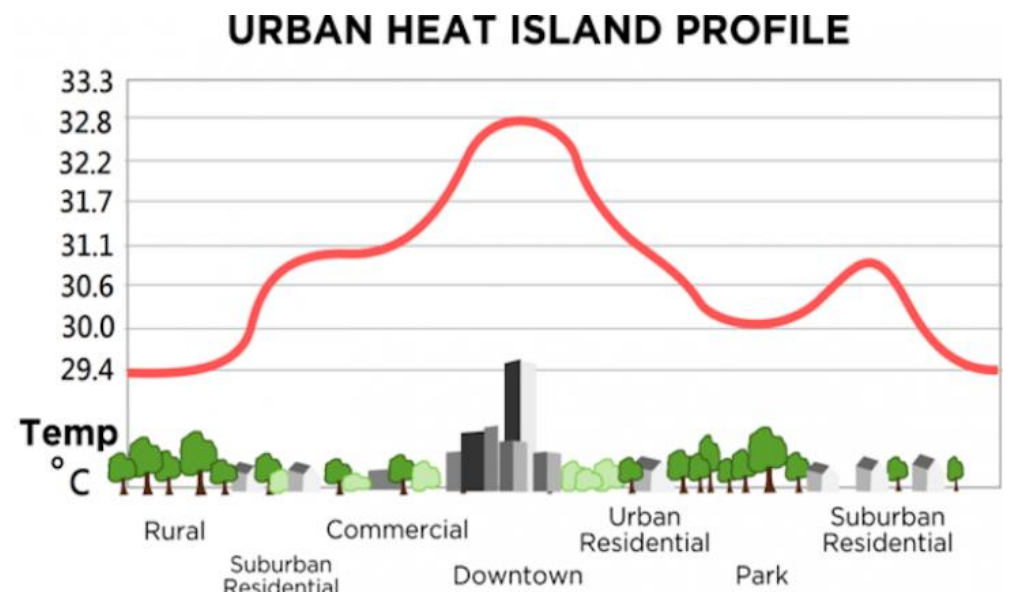

Figure 1 - Heat island behavior profile. Source: Correa (2006).

Many of the factors associated with the formation of Urban Heat Island include the use of building materials, mainly concrete and asphalt, as well as metals and glass. These materials have a thermal capacity different from the natural vegetation cover, which will result in large differences in temperature, especially at night, when the surface will release more heat to the atmosphere (Comarazamy et al., 2007; Souza and Alvalá, 2014).

Due to population growth and the process of urbanization, the local microclimate seriously affected, with the city showing, of course, temperature differences. Because of this difference, the population ends up suffering some discomfort with very cold nights or very hot days, or vice versa. The degree of comfort or thermal discomfort felt by people is due to the combined effect of metabolic heat production, environmental factors such as wind speed, air temperature and relative humidity, among others, and the type of clothing used by the person (Maia, 2002; Gouvêia, 2006). An example of this is the comfort definition stipulated by ASHRAE (American Society of Heating Refrigerating and Air Conditioning Enginners), standard 55/1994: thermal comfort defined as "the condition of the mind that expresses satisfaction with the external environment".

Two groups of major factors influence both the psychological and the physiological aspects: individual factors and environmental factors. They comprise the individual factors (the level of physical activity, metabolism, resistance of the clothes, acclimatization, age, sex, among others). The environmental factors that affect thermal comfort are air temperature, air humidity, wind speed and average radiant temperature (Maia, 2002).

In this context, there is a tendency to idealize that islands of heat can be better identified in cities with an extensive urban area and high population (Kim and Baik, 2004; Miao et al., 2008 and Civerolo et al., 2007). The objective this work was to identify the evolution and consequent presence or absence of heat islands in five small, medium and large cities located in the Northeast region of Brazil, using images from the Landsat 5 and 8 satellites, for years selected from the 
1980s, and local weather data to verify if there is a change in the degree of local thermal comfort.

The choice of these cities was due to the fact that at certain seasons of the year they presented a dry season with little or no cloudiness on most days, a factor that interferes with the quality of the results to be obtained through remote sensing in more specific areas. Among the 9 state capitals of the Northeast, 8 are coastal cities, with a regular presence of cloudiness, even outside the rainy season. Due to this, it was decided to work with Teresina, the capital of the Piauí state, because it is the only capital not located on the coast, and with four cities in the Ceará (Quixeramobim), Rio Grande do Norte (Mossoró), Paraíba (Sousa) and Bahia (Vitória da Conquista), due to the fact that images of good quality and without presence of cloudiness are obtained. These cities were also selected because they presented positive trends of temperature increase, in their respective meteorological stations.

\section{Materials and methods}

\subsection{Study area}

The area of study of this research includes the municipalities and respective urban area of Teresina-PI $\left(5.08^{\circ} \mathrm{S}, 42.82^{\circ} \mathrm{W}, 74.4 \mathrm{~m}\right)$, Quixeramobim-CE $\left(5.17^{\circ} \mathrm{S}\right.$, $\left.39.28^{\circ} \mathrm{W} ; \quad 79.5 \mathrm{~m}\right), \quad$ Sousa-PB $\left(6.75^{\circ} \mathrm{S}, \quad 38.22^{\circ} \mathrm{W}\right.$, $233.1 \mathrm{~m})$, Mossoro-RN $\left(5.2^{\circ} \mathrm{S}, 37.3^{\circ} \mathrm{W}, 36 \mathrm{~m}\right)$ and Vitoria da Conquista-BA $\left(14.88^{\circ} \mathrm{S} ; 40.80^{\circ} \mathrm{W}, 874.8 \mathrm{~m}\right)$, as shown in Figure 2.

In Teresina, annual rainfall and average temperature are $1393.2 \mathrm{~mm} /$ year and $27.1^{\circ} \mathrm{C}$, respectively. The climate of Mossoro is characterized as hot semiarid, with average annual temperature of $28^{\circ} \mathrm{C}$ and rainfall index of $787.9 \mathrm{~mm} / \mathrm{year}$, concentrated between the months of February and May. The same climatic characteristic observed in Quixeramobim, with rainfall concentrated from February to May, with a precipitation of 857.7 $\mathrm{mm} /$ year and an annual average temperature of $26.5^{\circ} \mathrm{C}$. In Sousa, the annual precipitation rate is higher than in Mossoro and Quixeramobim, of the order of 995.5 $\mathrm{mm} /$ year and average annual temperature of $26.5^{\circ} \mathrm{C}$. Vitoria da Conquista characterized by having a milder climate due to its altitude $(875 \mathrm{~m})$. The average annual temperature is $22.1^{\circ} \mathrm{C}$; however, there have been records of the order of $10^{\circ} \mathrm{C}$ in the winter months (July and August). The annual precipitation is $795.2 \mathrm{~mm}$, with a dry season between May and September (INMET, 2010).

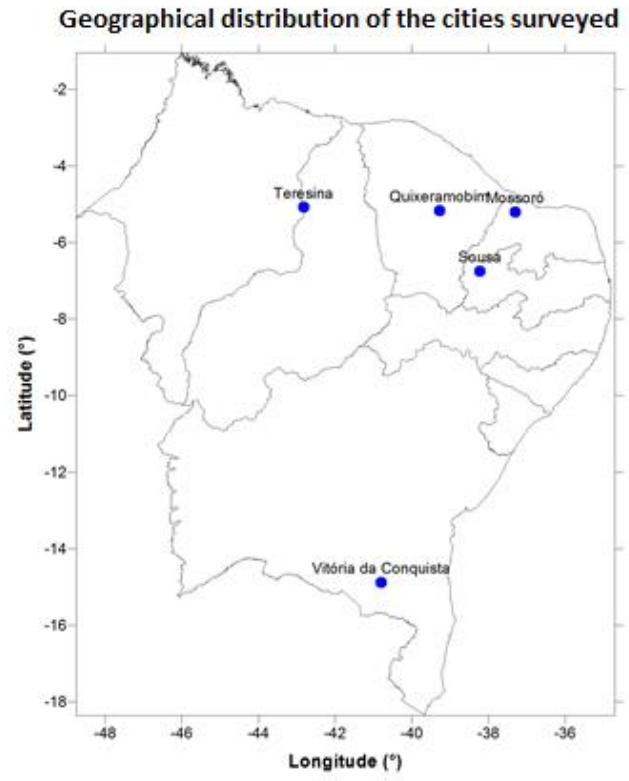

(a)
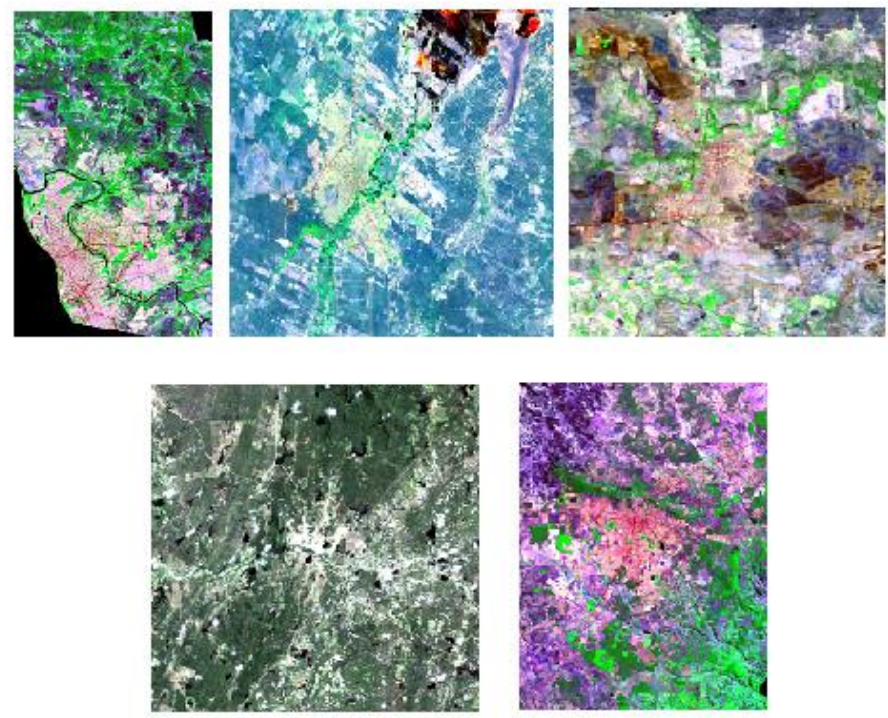

(b)

Figure 2 - (a) Geographic distribution of the municipalities selected for study and (b) Color combination of the municipalities of Teresina (PI), Mossoro (RN), Sousa (PB), Quixeramobim (CE) and Vitoria da Conquista (BA). 


\subsection{Satellite Images}

Satellite imagery of the Landsat program used, consisting of a series of orbital Earth observation missions managed by NASA in conjunction with the United States Geological Survey since 1972 (Campbell, 1987).

The images used are the Thematic Mapper Sensor (TM) of the Landsat 5 satellite and the Thermal Infrared Sensor (TIRS) of the Landsat 8 satellite, in the thermal bands, in order to visualize the possible temperature increases in each area along the years.

The Landsat 5 has 7 bands, 6 with spatial resolution of $30 \mathrm{~m}$, and 1 thermal band with spatial resolution of $120 \mathrm{~m}$. Already the Landsat 8 has 11 bands, two bands in the thermal infrared wavelength bands 10 and 11. As the analysis performed is directly related to the temperature of hot surfaces, only the band 10 of the thermal sensor was used, since it is better sensor for these types of targets, because, according to the Law of Vienna, that is, the higher the target temperature, the lower the wavelength of the peak of maximum radiant emitance.

In this research, the surface temperature initially obtained in order to ascertain the increase of the temperature of the urban environment in selected dates of the 1980s, 1990s, 2000s and the year of 2016. With the data of the images, it was possible to also calculate the dew point temperature to then obtain the respective $\mathrm{ID}_{\mathrm{K}}$ values for the selected cities. For the purposes of comparison and validation of the results, the data series observed in the meteorological stations of the cities used to analyze the annual average of the temperature and the IDK of the years of the images selected for each city.

2.3. Kawamura Discomfort Index $\left(\mathrm{ID}_{\mathrm{K}}\right)$ obtained by Satellite Images

The calculation of the $\mathrm{ID}_{\mathrm{K}}$ is based on the mean ambient temperature (T) and the dew point temperature (Td), both in ${ }^{\circ} \mathrm{C}$, which in turn is related to the relative humidity, since it is the temperature necessary for the condensation of water (Vital et al., 2012). The same achieved by equation 1 below:

$I D_{K}=0,99 \times T+0,36 \times T_{d}+41,5$

Where: $\mathrm{T}$ is the air temperature and $\mathrm{Td}$ is the temperature of the dew point, both in ${ }^{\circ} \mathrm{C}$.

The table 1 shows the index rating in terms of thermal sensation.

Table 1 - Kawamura Discomfort Index rating (ONO and KAWAMURA, 1991).

\begin{tabular}{c|c}
\hline Values of $\mathbf{I D}_{\mathbf{K}}$ & Thermal sensation \\
\hline $\mathbf{I D}_{\mathbf{K}}>80$ & Stress due to heat \\
$75<\mathbf{I D}_{\mathbf{K}}<80$ & Heat discomfort \\
$60<\mathbf{I D}_{\mathbf{K}}<75$ & Comfortable \\
$55<\mathbf{I D}_{\mathbf{K}}<60$ & Cold discomfort \\
$\mathbf{I D}_{\mathbf{K}}<55$ & Stress due to cold \\
\hline
\end{tabular}

Air temperature $(\mathrm{T})$ is an expression used in meteorology to translate the reigning temperature into a point in the atmosphere and the dew point temperature (Td) is defined as the temperature at which water vapor is suspended in atmosphere would condense under the same pressure. The values of air temperature $(\mathrm{T})$ and dew point temperature $(\mathrm{Td})$ are essential to obtain the $\mathrm{ID}_{\mathrm{K}}$. The temperature of the dew point $(\mathrm{Td})$ was obtain following the following procedure:

- Initially, the radiance is estimated by the following equations for both Landsat 5 (2) and 8 (3), respectively:
$L_{\mathbb{Z}}=\left(\frac{L_{\text {maxx }}-L_{\text {min }}}{D N_{\text {max }}}\right) * D N+L_{\text {minn }}$

What:

$L_{\lambda}$ - spectral radiance at the top of the atmosphere

(TOA) $\left(\mathrm{W} / \mathrm{m}^{2 *} \mathrm{srad}^{*} \mu \mathrm{m}\right)$;

$L_{\text {máx }}$ and $L_{\text {min }}$ - Calibration constants for each band

$D N_{\text {máx }}$ - digital number maximum $\left(\mathrm{DN}_{\text {máx }}=255\right)$

$D N$ - digital number of each pixel

$L_{\mathbb{Z}}=M_{L} * Q_{\text {eal }}+A_{L}$ 
What:

$L_{\lambda}$ - spectral radiance at the top of the atmosphere

(TOA) $\left(\mathrm{W} / \mathrm{m}^{2 *} \mathrm{srad}^{*} \mu \mathrm{m}\right)$;

$M_{L}$ - band specific multiplicative factor;

$A_{L}$ - band specific additive factor;

$\mathrm{Q}_{\mathrm{cal}}$ - digital number image (DN).

- After calculating the radiance, the air temperature $(\mathrm{T})$ is estimated by the following process, according to equation 4 :

- As the temperature is given in Kelvin, it should be converted to $\left({ }^{\circ} \mathrm{C}\right)$ using the following equation:

$\mathrm{T}\left({ }^{\circ} \mathrm{C}\right)=\mathrm{T}(\mathrm{K})-273,15$
$T=\frac{K_{2}}{\ln \left(\frac{K_{1}}{L_{\alpha}}+1\right)}$

What:

$\mathrm{T}$ - brightness temperature $(\mathrm{K})$

$L_{\lambda}$ - spectral radiance at the top of the atmosphere (TOA) $\left(\mathrm{W} / \mathrm{m}^{2 *} \operatorname{srad}^{*} \mu \mathrm{m}\right)$;

$K_{l}$ - band specific thermal conversion constant;

$K_{2}-$ specific thermal conversion constant.

In light of the above, bands chosen for this analysis were band 6 of Landsat 5 and band 10 of Landsat 8. Therefore, the values of the constants described above are present in Table 2:

Table 2 - Constants used to convert the image to radiance and temperature.

\begin{tabular}{c|c}
\hline Landsat 5 & Landsat 8 \\
\hline $\mathrm{L}_{\text {máx }}=15,303$ & $\mathrm{M}_{\mathrm{L}}=3,3420 \mathrm{e}^{-04}$ \\
\hline $\mathrm{L}_{\text {mín }}=1,2378$ & $\mathrm{~A}_{\mathrm{L}}=0,10000$ \\
\hline $\mathrm{K}_{1}=607,76$ & $\mathrm{~K}_{1}=774,89$ \\
\hline $\mathrm{K}_{2}=1260,56$ & $\mathrm{~K}_{2}=1321,08$ \\
\hline
\end{tabular}

- To supplement the $\mathrm{ID}_{\mathrm{K}}$ calculation process, the partial pressure of the water vapor (ea), defined as the pressure of the water vapor content contained in the air, is estimated under normal atmospheric conditions. To obtain the saturation pressure of the water vapor, we used equation 7. The partial pressure of the water vapor is given by the equation:

$\mathrm{ea}=\mathrm{es}(\mathrm{tu})-0,00066(1+0,00115 \mathrm{tu})(\mathrm{t}-\mathrm{tu}) \mathrm{P}$

- Quanto não se tem tu, mas se tem UR, pode se obter ea fazendo: ea $=\mathrm{es}(\mathrm{t}) \mathrm{xUR} / 100$

$e_{a}=6,1078 * e^{\frac{17,3 * T}{237,3+T}}$
- After a ea is obtained, $\mathrm{Td}$ is calculated according to equation (8) described below:

$T_{d}=\frac{237,3 * \ln \left(\frac{e_{\kappa}}{e_{0}}\right)}{\left(17,2688-\ln \left(\frac{e_{\alpha}}{e_{0}}\right)\right)}$

Where Td is the temperature of the dew point $\left({ }^{\circ} \mathrm{C}\right)$; ea is the partial pressure of water vapor $(\mathrm{hPa})$; and eo is the partial pressure of the water vapor when the air temperature is $0^{\circ} \mathrm{C}=6.1078 \mathrm{hPa}$.

Finally, we estimate the $\mathrm{ID}_{\mathrm{K}}$, through equation 2 , already described previously for the images. Table 3 shows, for each municipality, the respective dates of the satellites images to process the information relevant to the survey. 
Table 3 - Municipalities and dates of the chosen images of the Landsat 5 and 8 satellites.

\begin{tabular}{c|c}
\hline City & Date of Image \\
\hline Teresina $(\mathrm{PI})$ & $25 / 08 / 1987 ; 18 / 10 / 1995 ; 07 / 07 / 2010 ; 28 / 11 / 2016$ \\
\hline Mossoró (RN) & $04 / 08 / 1987 ; 29 / 09 / 1996 ; 15 / 07 / 2003 ; 20 / 09 / 2016$ \\
\hline Sousa $(\mathrm{PB})$ & $01 / 10 / 1985 ; 20 / 08 / 1993 ; 24 / 09 / 2000 ; 07 / 11 / 2016$ \\
\hline Quixeramobim $(\mathrm{CE})$ & $23 / 07 / 1986 ; 22 / 06 / 1998 ; 24 / 07 / 2004 ; 26 / 08 / 2016$ \\
\hline Vitória da Conquista (BA) & $26 / 06 / 1988 ; 11 / 08 / 1993 ; 30 / 07 / 2006 ; 10 / 08 / 2016$ \\
\hline
\end{tabular}

\subsection{Observed Data}

Observed mean temperature and relative humidity data used to calculate the $\mathrm{Td}$ and then the $\mathrm{ID}_{\mathrm{K}}$ of the years of the images chosen to compare the observed mean temperature and the $\mathrm{ID}_{\mathrm{K}}$ in the respective years.

\section{Results and discussion}

In this topic will be presented the results of the surface temperature and $\mathrm{ID}_{\mathrm{K}}$ analyzes for the respective selected dates of each city.

\subsection{Surface Temperature}

The surface temperature used to differentiate the temperature of the urban area in relation to adjacent rural or suburban areas as a way of identifying Heat Island. In these images, the lighter the point, the higher the pixel temperature.

In this studies, LOMBARDO (2005), BIAS et al. (2003) and BAPTISTA (2002), showed that the increase of urban areas in a disorganized way can affect the local microclimate, causing, mainly, the increase of the local temperature. LOMBARDO (2005) states that "a metropolis without adequate land-use planning, lacking adequate vertical integration and occupation parameters, especially where it grows at a rapid rate and with few technical resources, can endanger the quality of life of its inhabitants".

Teresina (PI) (Figure 3) can be considered a classic case of urban island, where the temperature of the urban area (lighter pixels) is higher than the neighboring area (darker pixels). Among the images $3 \mathrm{a}$ to $3 \mathrm{c}$, obtained by Landsat 5 , Figure $3 \mathrm{c}$ of the year 2010 presents the best discretization of the urban area and consequent heat island. Figure 3, obtained by
Landsat 8, also allows to identify the urban area warmer than the neighborhood in the year 2016, and its difference in relation to the previous images is due to the better spatial resolution of the satellite.

Figure 4 shows the sequence of surface temperature images for Mossoro. For the images of 1987 (Figure 4a) and 2003 (Figure 4c), it is clear that the predominance of pixels with lighter shades than the surroundings in the area of the rectangle where the urban area is located, evidencing the island of heat in relation to neighborhood. In the images of the years of 1996, one also perceives the effect of the heat island in lower intensity (Figure $4 \mathrm{~b}$ ). The surface temperature field of July 15, 2003 is the one that best depicts both the urban area, warmer than the surrounding area, and the expansion of the urban area in relation to previous years. Mossoro is considered one of the hottest cities in the northeastern semi-arid region. Nascimento et al. (2014) showed, through images from the Landsat-5, from July 6, 1994, July 6, 2000 and July 31, 2009, that Mossoro underwent great urban growth and suppression of green areas, with consequent increase of the temperature in the urbanized area in relation to the surroundings.

The same behavior observed in Mossoro can be observed in Sousa (PB), as can be seen in Figure 5. The areas that have milder temperatures are find around the urban center.

In Quixeramobim (CE), the urban area is considerably warmer than its surroundings following the maps of Figure 6. Large areas probably vegetated and with milder temperatures are seen in all images, especially in the first three years of 1986, 1998 and 2004 (Figures 6a, 6b and 6c). These results allow us to infer that it is possible to identify possible heat islands not only in medium to large cities. 

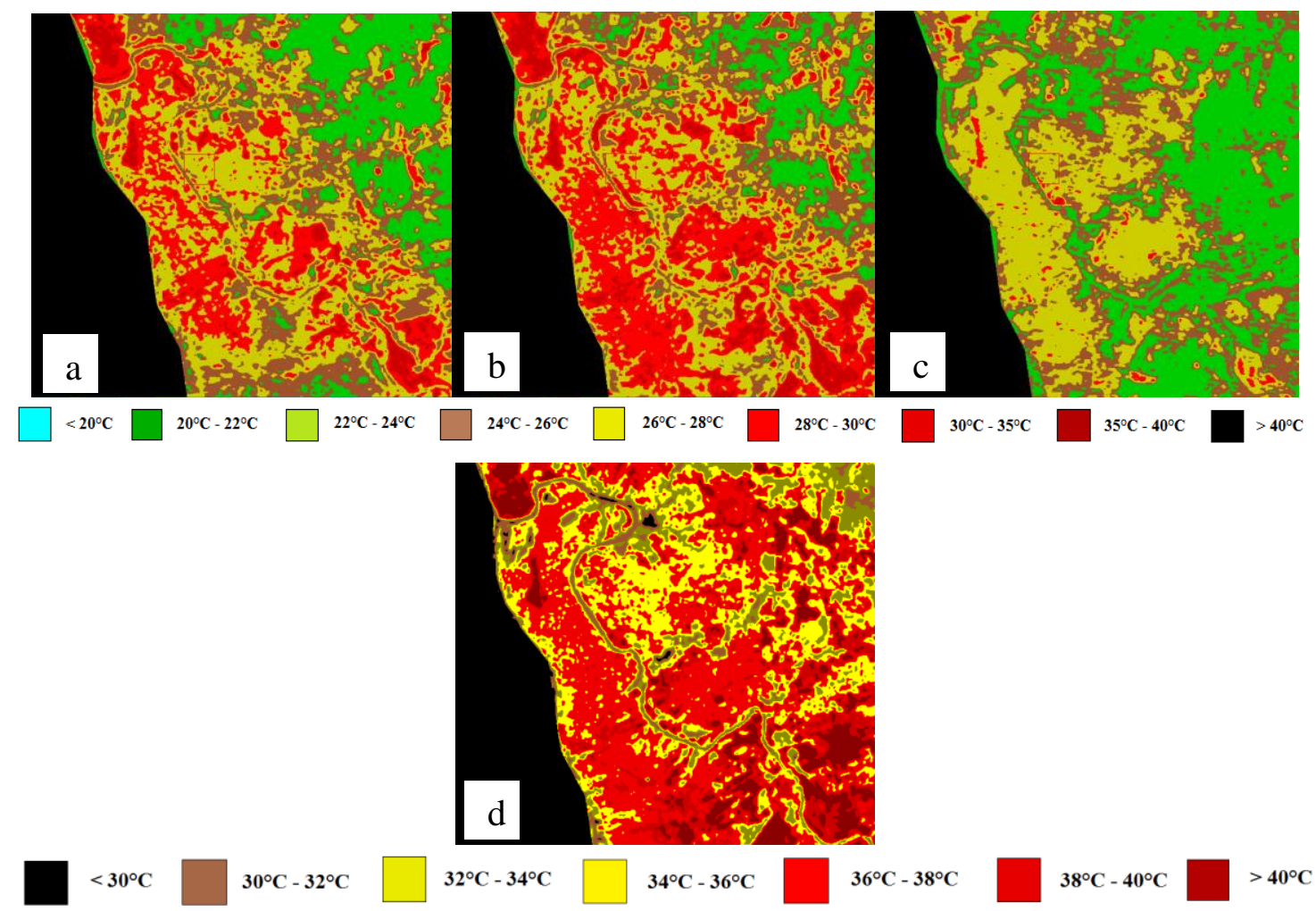

Figure 3- Surface temperature of Teresina (PI) for the following dates: (a) 25/08/1987, (b) 18/10/1995, (c) 07/07/2010 e (d) $28 / 11 / 2016$.

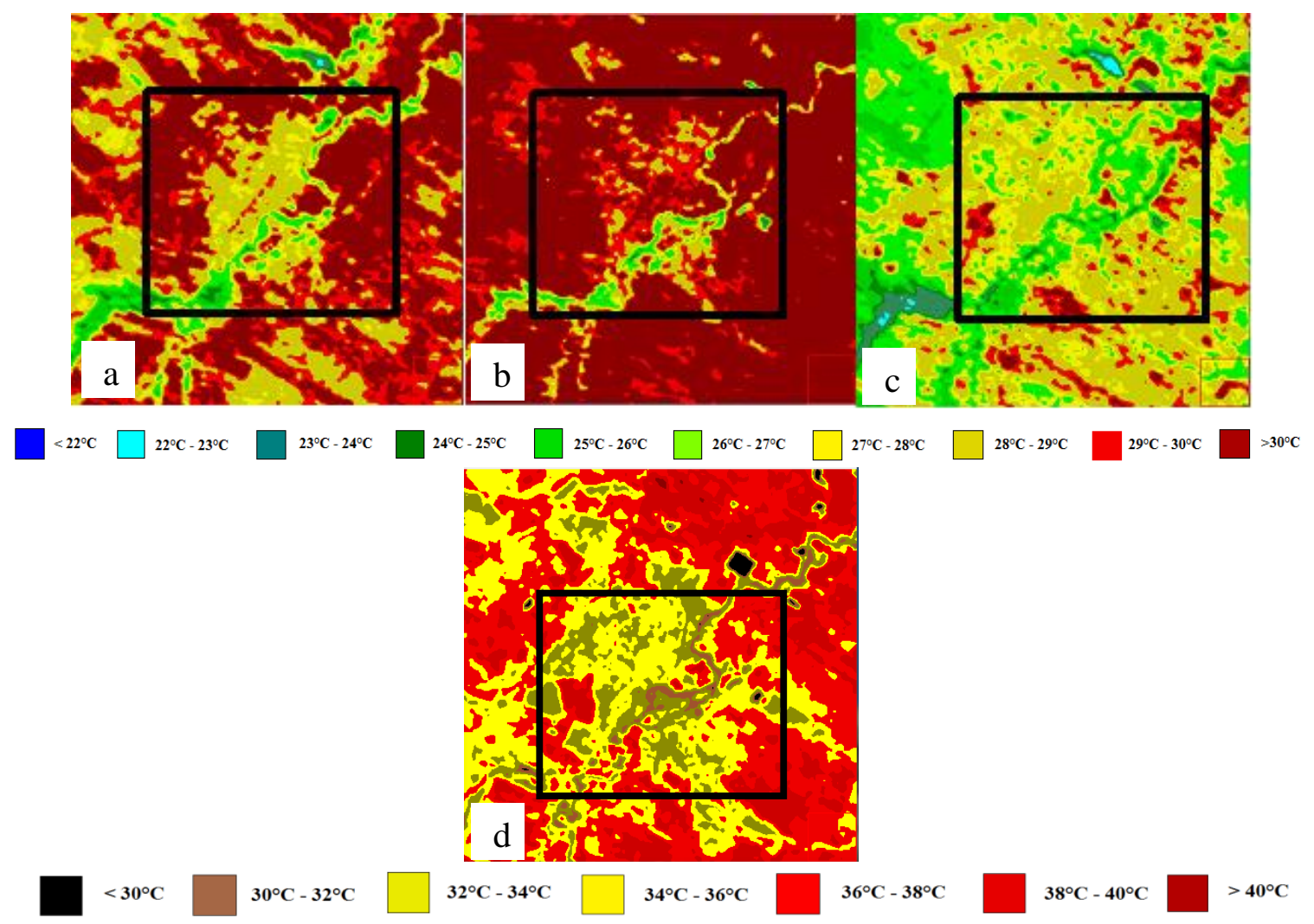

Figure 4 - Surface temperature of Mossoro (RN) for the following dates: (a) 04/08/1987, (b) 29/09/1996, (c) $15 / 07 / 2003$ e (d) 20/09/2016. 


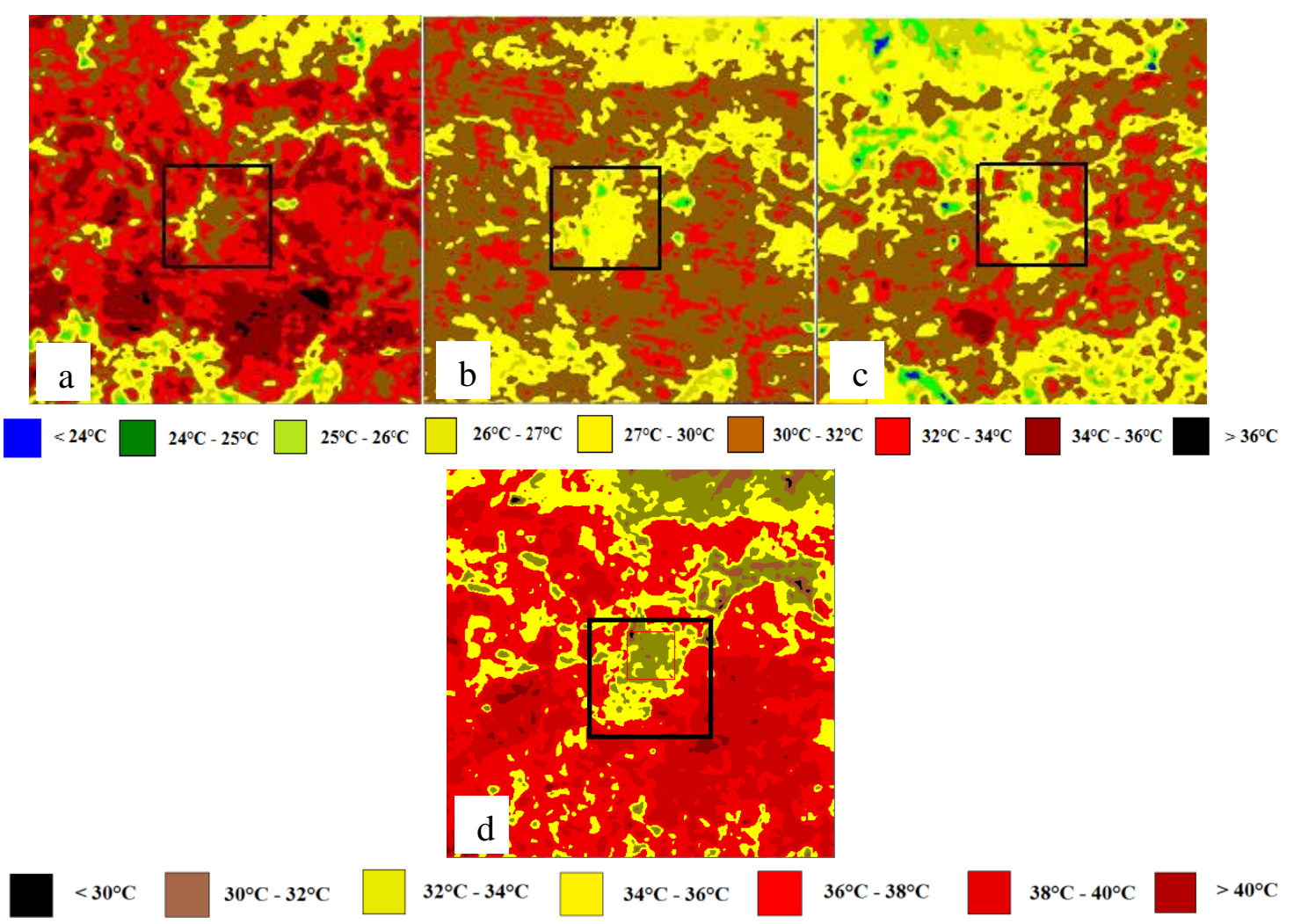

Figure 5 - Surface temperature of Sousa (PB) for the following dates: (a) 01/10/1985, (b) 20/08/1993, (c) 24/09/2000 e (d) $07 / 11 / 2016$.

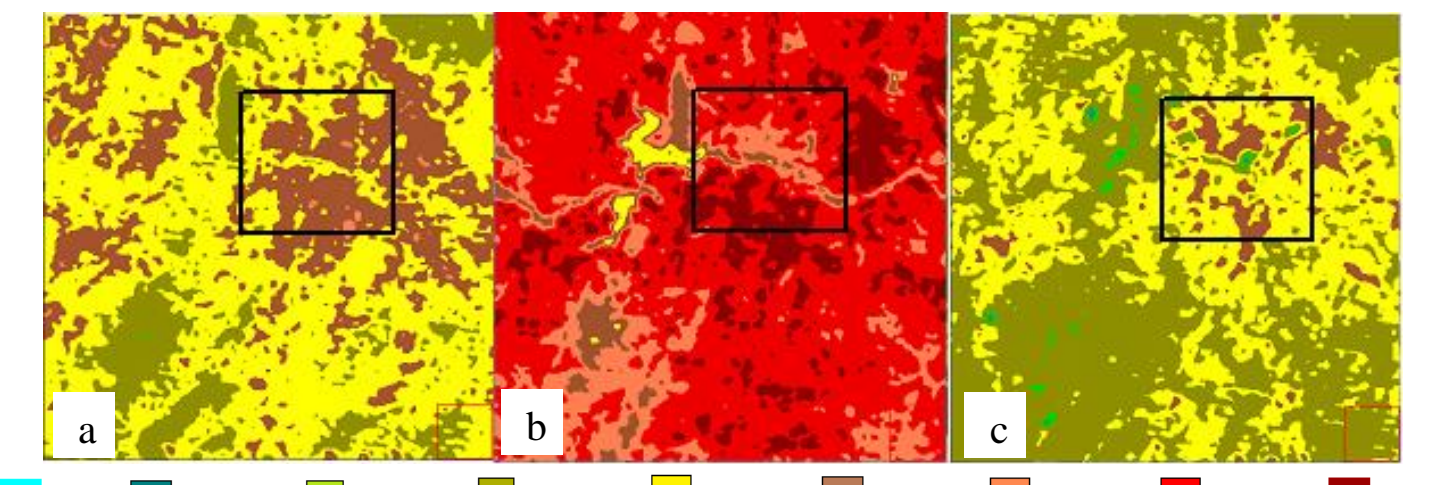

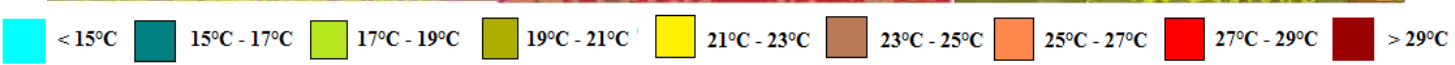
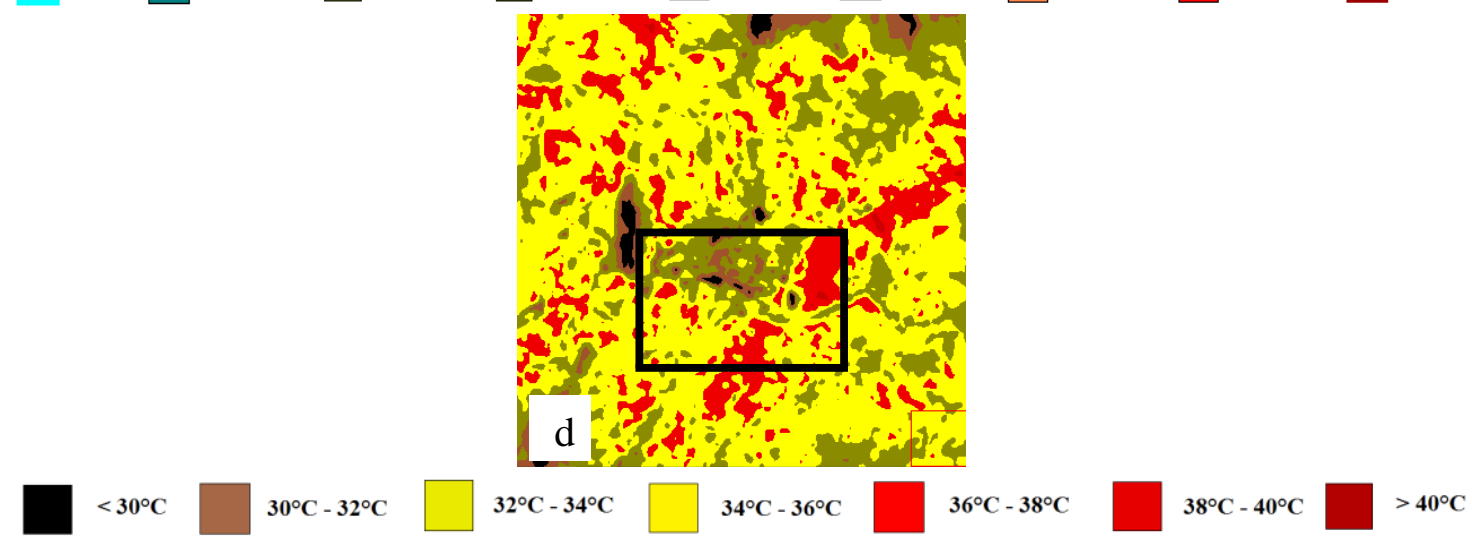

Figure 6 - Surface temperature of Quixeramobim (CE) for the following dates: (a) 23/07/1986, (b) 22/06/1998, (c) 24/07/2004 e (d) 26/08/2016.

R.L. Costa et al./ Journal of Hyperspectral Remote Sensing 7 (2017) 408-422 
Vitoria da Conquista (BA), as previously mentioned, is among the cities studied the milder temperatures due to its altitude of $875 \mathrm{~m}$. Therefore, the temperature differences, slightly higher than most of its surroundings, are perceived more gently, especially in images 8 a to relative to June 20 and July
30 of the years 1988 and 2006, obtained with the Landsat satellite 5. The image of 10/08/2016 obtained with Landsat 8 allows to perceive in addition to the expansion of the urban area, the higher temperatures in the same in relation to the colder neighborhood.

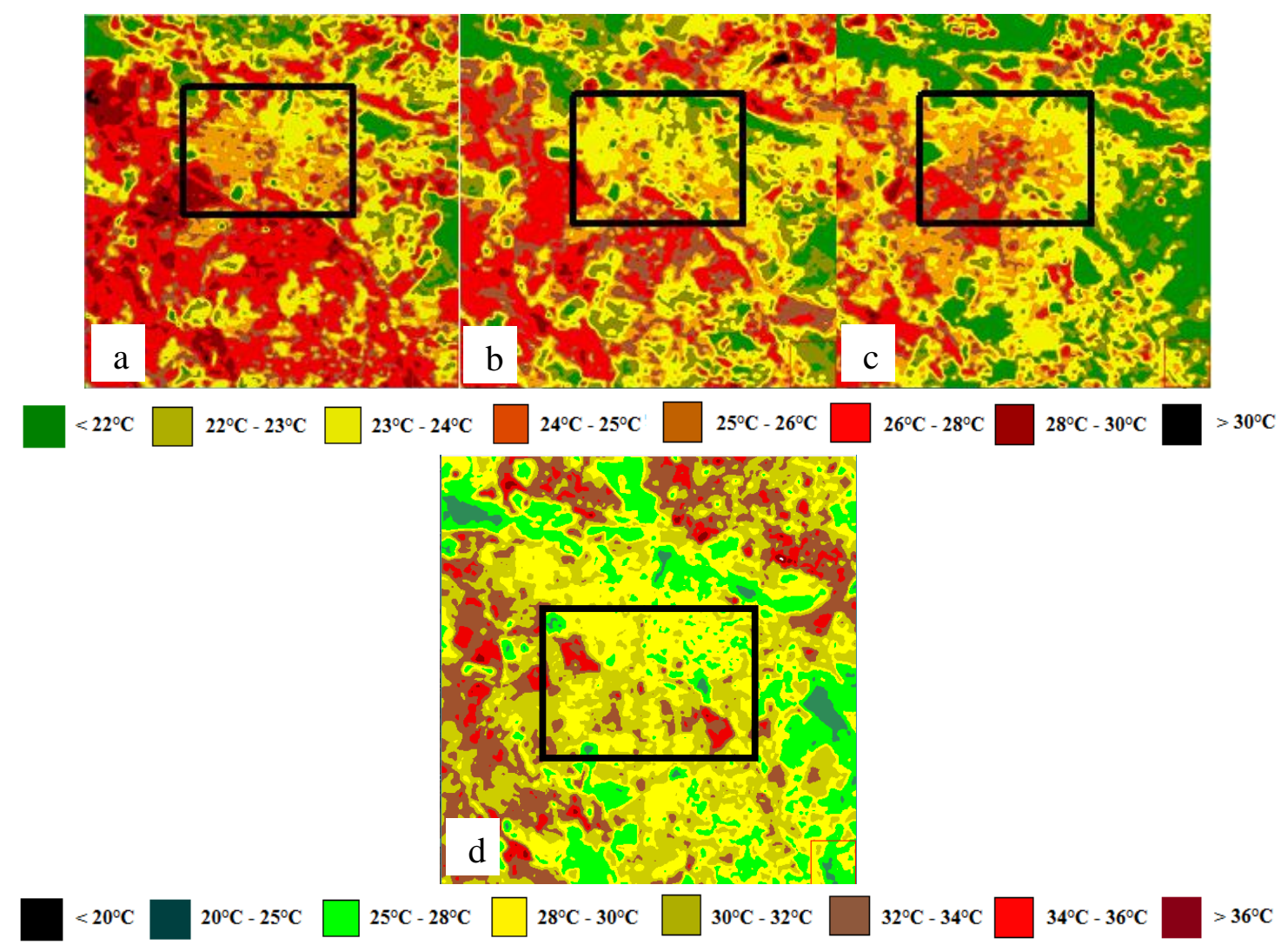

Figure 7 - Surface temperature of Vitoria da Conquista (BA) for the following dates: (a) 26/06/1988, (b) 11/08/1993, (c) $30 / 07 / 2006$ e (d) $10 / 08 / 2016$.

\subsection{Thermal Discomfort Index $\left(\mathrm{ID}_{\mathrm{K}}\right)$}

In this topic, we present the results of the $\mathrm{ID}_{\mathrm{K}}$ for the cities under study. For a better evaluation of the temperature and $\mathrm{ID}_{\mathrm{K}}$ of these cities, an ROI (Region of Interest) was extracted from the urban area of each municipality, in order to better visualize the behavior of these variables in the images of each selected year. Regions of Interest (ROIs) are portions of images selected graphically or selected by other means, such as threshold. ROIs can be irregularly shape and are typically use to extract statistics for sorting, masking, and other operations.

The justification for using ROI information is due to the difficulty in working with urban areas, which have a great diversity of targets, mainly due to the great distinction of materials used in construction, incurring a wide variety of albedos (BAPTISTA, 2010). Baptista and Nascimento (2016) even suggest the use of city night-lights as a way to minimize the diversity of targets in the generation of urban growth scenarios.

Figure $8 \mathrm{a}$ and $8 \mathrm{~b}$ plot the variation of the surface temperature and the $\mathrm{ID}_{\mathrm{K}}$ for the urban area of Teresina. Due to the already mentioned diversity of targets, there is great variability in both temperature and $\mathrm{ID}_{\mathrm{K}}$ values. In Teresina, it is observed that the highest temperatures for the urban area were observed in the image of the year 2016, followed by the image of the year of 1987, 1995 and 2010. The temperatures verified in some pixels exceed $40^{\circ} \mathrm{C}$. Since temperature is the main variable for the $\mathrm{ID}_{\mathrm{K}}$ calculation, the 
variation of the index in the images follows the same observed temperature pattern, with the $\mathrm{ID}_{\mathrm{K}}$ surpassing in the hottest pixels the value 85 , which represents intense heat stress.

As it is only the image for a day of each of the four years, nothing can be said about the average temperature and index for each year. Therefore, Figures 9a and 9b, which connect the mean

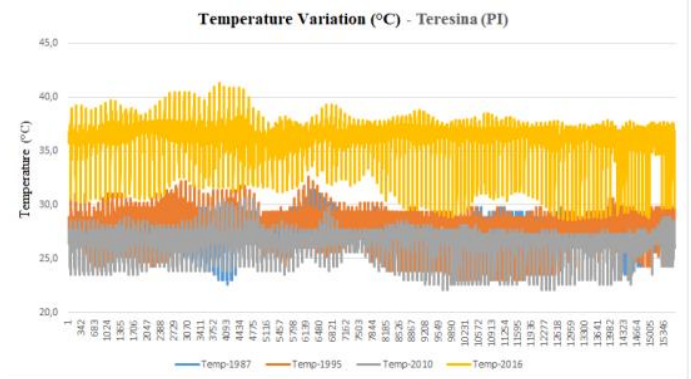

(a) temperature and $\mathrm{ID}_{\mathrm{K}}$ values for the years of the images, were constructed. It is observed that there is agreement only for the year 2016, with the highest annual averages of temperature and $\mathrm{ID}_{\mathrm{K}}$. What is observed is an increasing trend curve for the two variables, with 1995 being the year that presented the mildest temperatures, as well as for the $\mathrm{ID}_{\mathrm{K}}$.

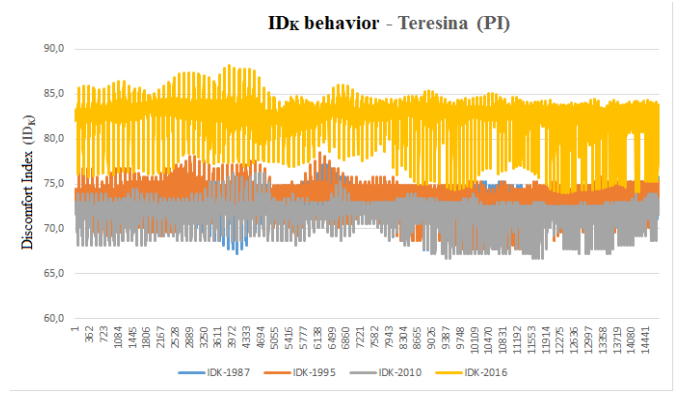

(b)

Figure 8 - (a) Temperature variation and (b) of the urban area's $\mathrm{ID}_{\mathrm{K}}$ of Teresina $(\mathrm{PI})$ for the four selected years.

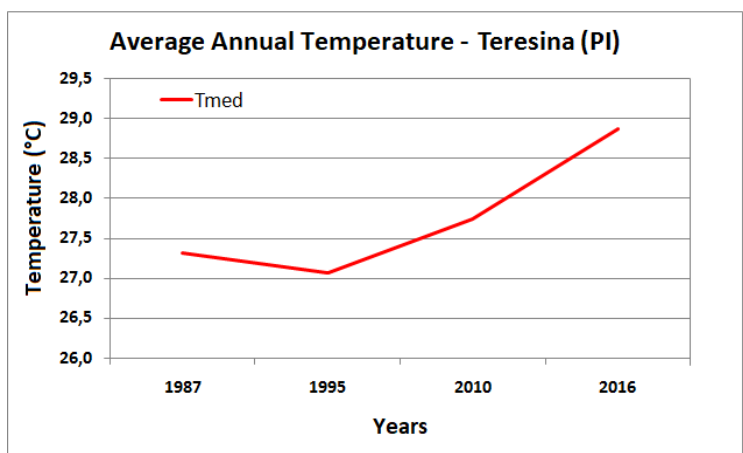

(a)

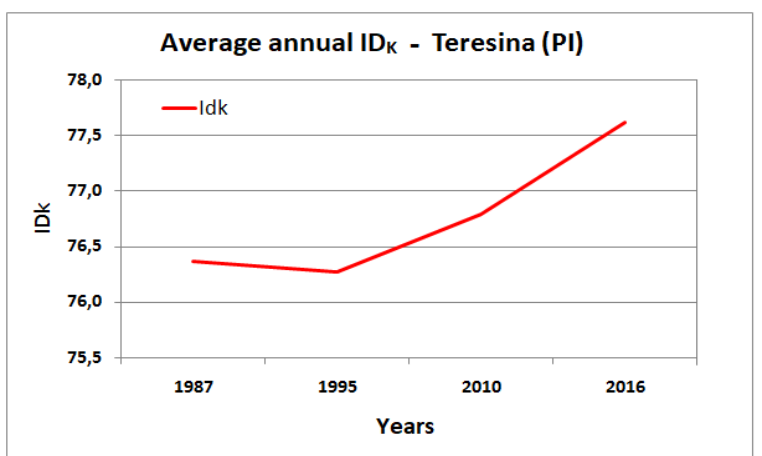

(b)

Figure 9 - Annual averages of temperature (a) and $\mathrm{ID}_{\mathrm{K}}(\mathrm{b})$ of Teresina (PI) for the selected four years.

Figure 10a and $10 \mathrm{~b}$ show the surface temperature and $\mathrm{ID}_{\mathrm{K}}$ variations for the urban area of Mossoro. In Mossoro, it is observed that the highest temperatures for the urban area were also observed in the image of the year 2016, followed by the image of the year of 1987, 1996 and 2003. The temperatures verified in some pixels reach $40^{\circ} \mathrm{C}$, with the $\mathrm{ID}_{\mathrm{K}}$ greater than 85 in the hottest pixels, which represents intense heat stress. For the cooler pixels, the $\mathrm{ID}_{\mathrm{K}}$ reaches values close to 65 or lower, classified as comfortable.

Figures 11a and $11 \mathrm{~b}$ show the mean annual values of temperature and $\mathrm{ID}_{\mathrm{K}}$ for the years of the images. It is observed that there is agreement only for the year 2016, with the highest annual averages of temperature and $\mathrm{ID}_{\mathrm{K}}$. What is observed is the year 1987 with temperatures lower among the four, with increase in 1996, later reduction in 2003 and again increase in 2016, same behavior for the $\mathrm{ID}_{\mathrm{K}}$. 


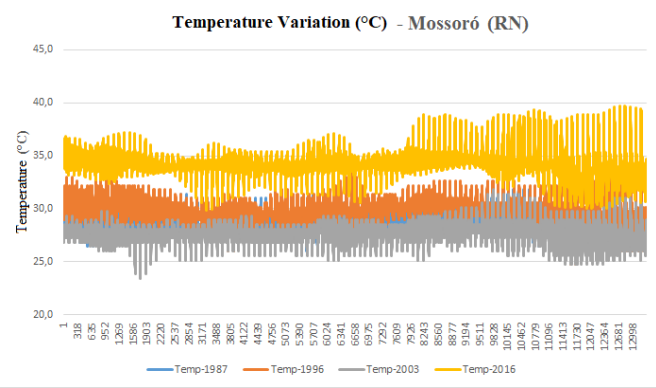

(a)

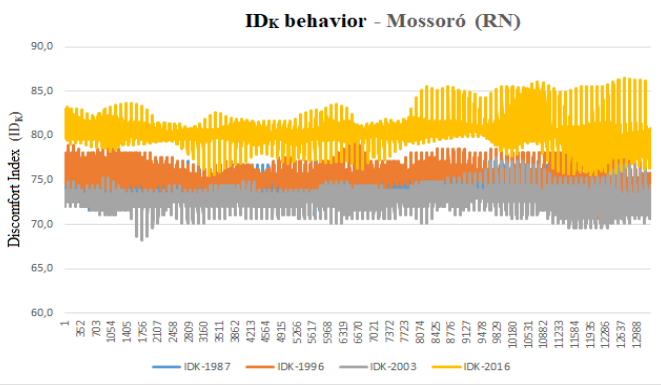

(b)

Figure 10 - (a) Temperature variation and (b) of the urban area's $\mathrm{ID}_{\mathrm{K}}$ of Mossoro (RN) for the four selected years.

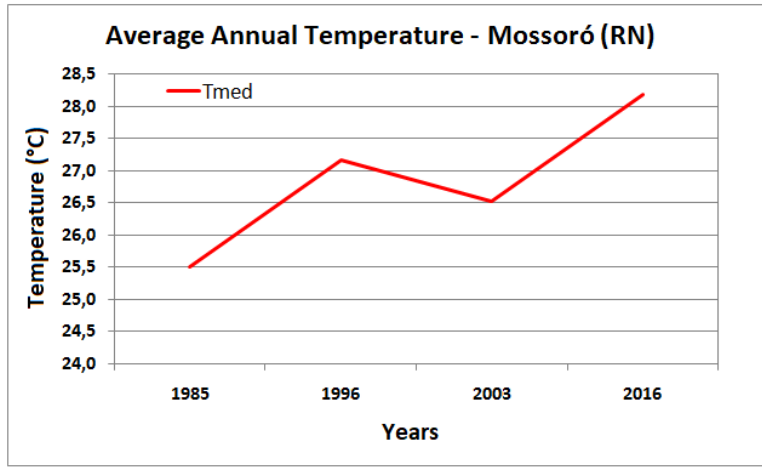

(a)

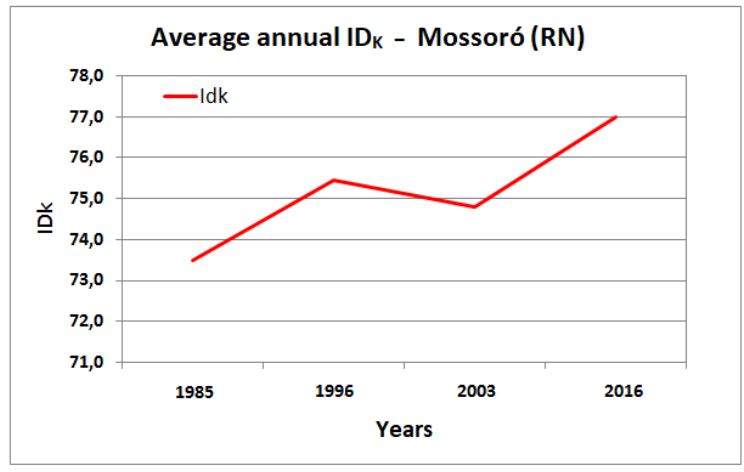

(b)

Figure 11 - Annual averages of temperature (a) and $\mathrm{ID}_{\mathrm{K}}(\mathrm{b})$ of Mossoro $(\mathrm{RN})$ for the selected four years.

Figures $12 \mathrm{a}$ and $12 \mathrm{~b}$ show the variation of the surface temperature and the IDK for the urban area of Sousa. Due to its smaller urban area and consequent lower number of pixels, the lowest data fluctuation is observed, with the highest temperatures for the urban area being observed in the images of the years 2016 and 1985, followed by the images of the years 2000 and 1993. The temperatures verified did not exceed $40^{\circ} \mathrm{C}$, with the lowest temperatures around $20^{\circ} \mathrm{C}$. The $\mathrm{ID}_{\mathrm{K}}$ is greater than 85 in the hottest pixels and less than
65 for the cooler ones, with the thermal comfort situation predominating.

Figure 13a shows the tendency for annual averages of temperature to increase between the years of the images, of the order of $2.5^{\circ} \mathrm{C}$ between the "coldest" year and the "hottest" year, between 1985 and 2016. The $\mathrm{ID}_{\mathrm{K}}$ behavior follows that of temperature, with the average comfort condition predominating (Figure 13b), reaching the heat discomfort class in 2016.

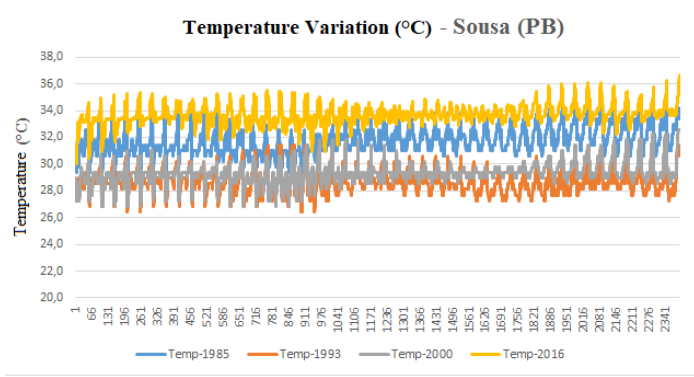

(a)

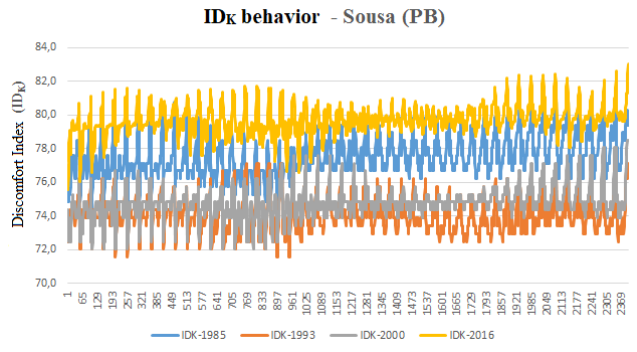

(b)

Figure 12 - (a) Temperature variation and (b) $\mathrm{ID}_{\mathrm{K}}$ of the urban area of Sousa (PB) for the selected four years. 


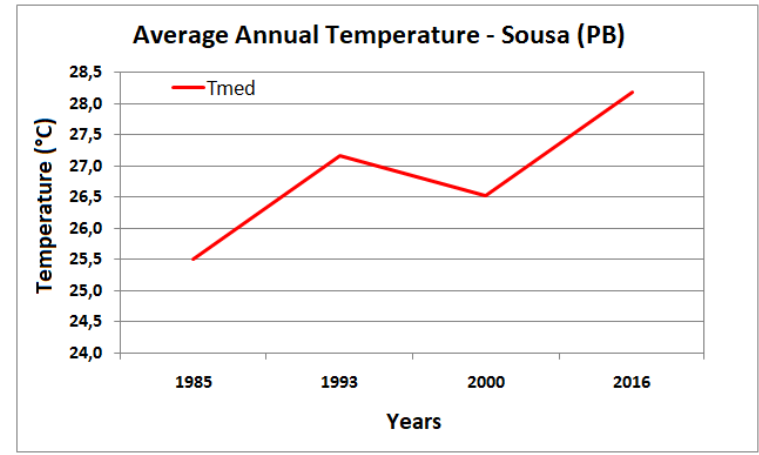

(a)

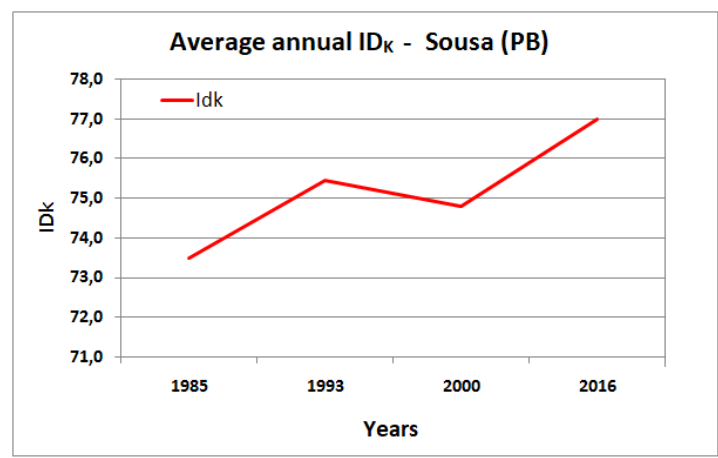

(b)

Figure 13 - Annual averages of temperature (a) and $\mathrm{ID}_{\mathrm{K}}(\mathrm{b})$ de Sousa $(\mathrm{PB})$ for the selected four years.

Figure 14a shows that the image that presented the year with pixels of higher temperature was that of the year 2016, followed by the years of 1998, 1986 and 2004. In 2016, the temperature is around $35^{\circ} \mathrm{C}$, in 1998 around $31^{\circ} \mathrm{C}$, an average difference of $4^{\circ} \mathrm{C}$ between the images of these two years. From the data plotted in Figure $14 \mathrm{~b}$, the mean $\mathrm{ID}_{\mathrm{K}}$ value was 67.1 in the 1986 image, 76.8 in the 1998 image, 64.3 in the 2004 image, and 80 in the 2016 image. It was soon observed predominance of pixels in the comfortable class in the images of 1986 and 2004, in the class of heat discomfort in the image of 1998 and discomfort/heat stress in the 2016.

The graph of Figure 15a shows that the mean annual temperature gradually increased between the years of the images obtained, as well as the average annual IDK, ranging from 74.5 to 77.5 , from a mean comfort condition for heat discomfort.

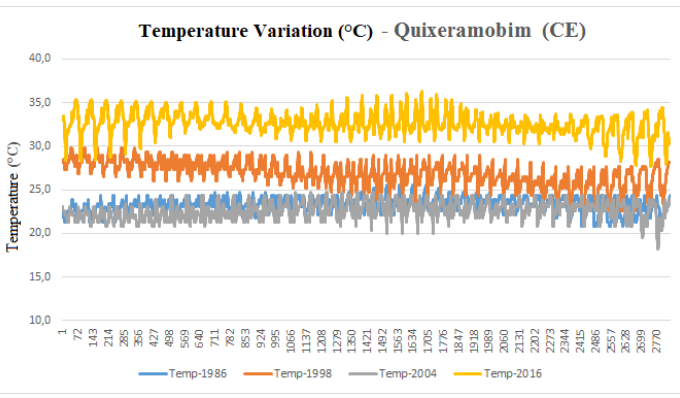

(a)

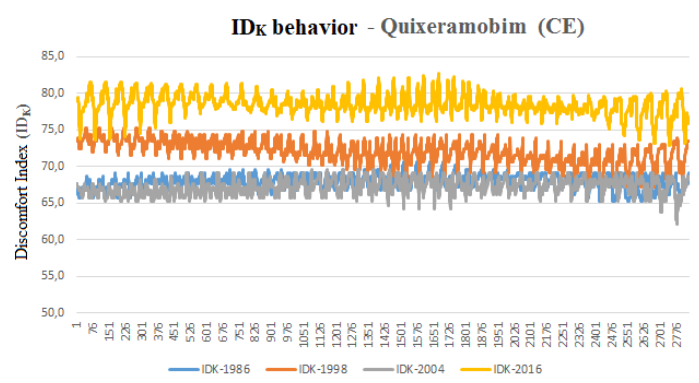

(b)

Figure 14 - Temperature variation (a) and $\mathrm{ID}_{\mathrm{K}}(\mathrm{b})$ behavior of the urban area of Quixeramobim (CE).

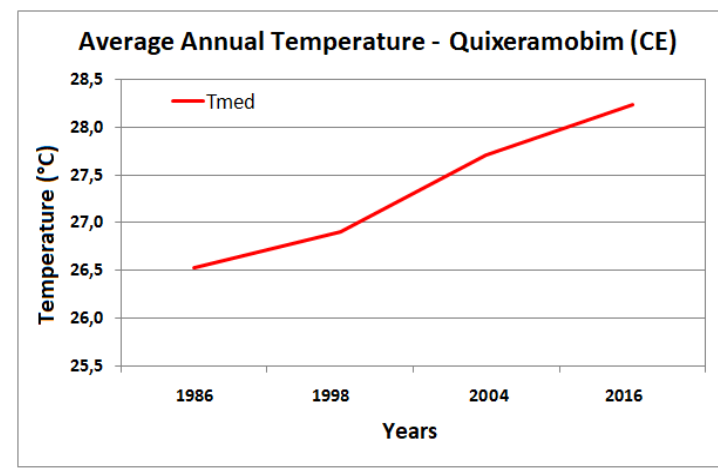

(a)

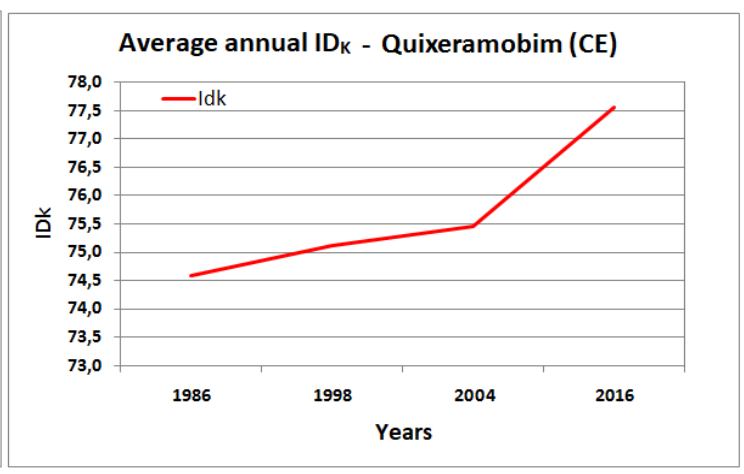

(b)

Figure 15 - Annual averages of temperature (a) and IDK (b) of Quixeramobim (CE) for the selected four years.

Figure 16a shows the surface temperature variation for Vitoria da Conquista. For the images of R.L. Costa et al./ Journal of Hyperspectral Remote Sensing 7 (2017) 408-422 the years 1988, 1993, 2006 and 2016, the average temperatures of the pixels were of $24^{\circ} \mathrm{C}, 21^{\circ} \mathrm{C}, 24^{\circ} \mathrm{C}$ 
and $31{ }^{\circ} \mathrm{C}$, highlighting the recent increase of the temperatures of 2016 already verified in the previous cities. Regarding the $\mathrm{ID}_{\mathrm{K}}$ shown in Figure $16 \mathrm{~b}$, the mean values of the pixels were $69,65,69$ and 77 , prevailing conditions of thermal comfort observed in the first three years and heat discomfort in 2016.

In relation to the annual averages of the average temperature observed in the years of the images, there was little variation between the values of 1988, 1993 and 2006, which presented average annual temperatures between 20 and $20.5^{\circ} \mathrm{C}$, reaching $21.5^{\circ} \mathrm{C}$ in 2016. The IDK's average annual pattern between these years ranged from 67.2 to 68.2 in the comfortable class.

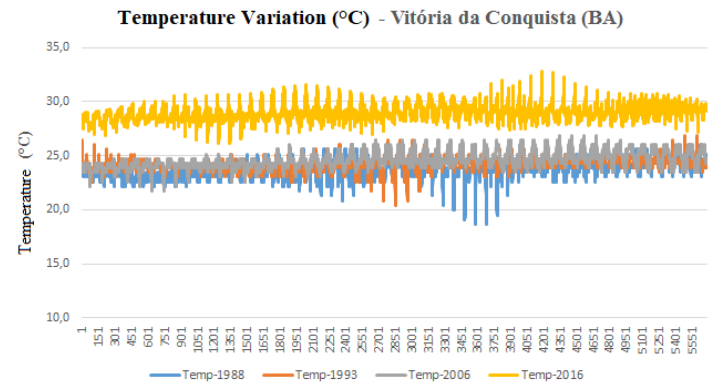

(a)

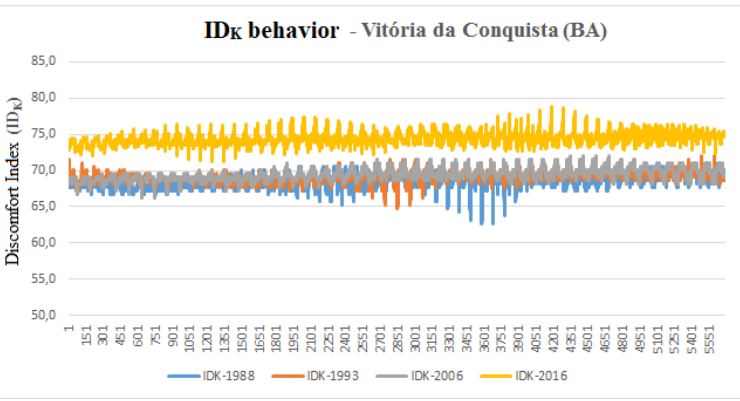

(b)

Figure 16 - Temperature variation (a) and $\mathrm{ID}_{\mathrm{K}}(\mathrm{b})$ behavior of the urban area of Vitoria da Conquista (BA).

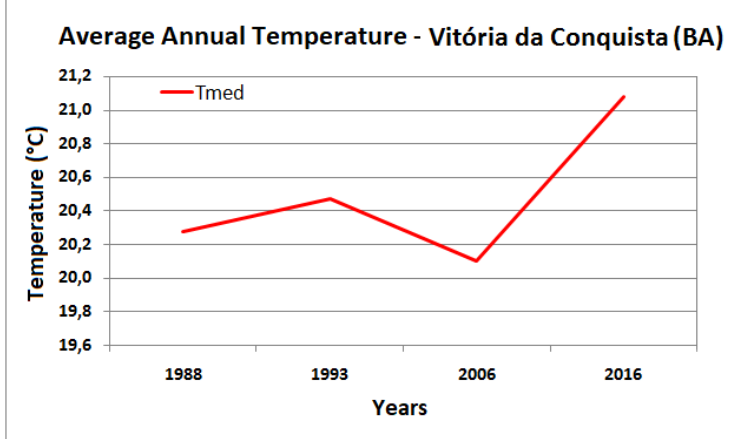

(a)

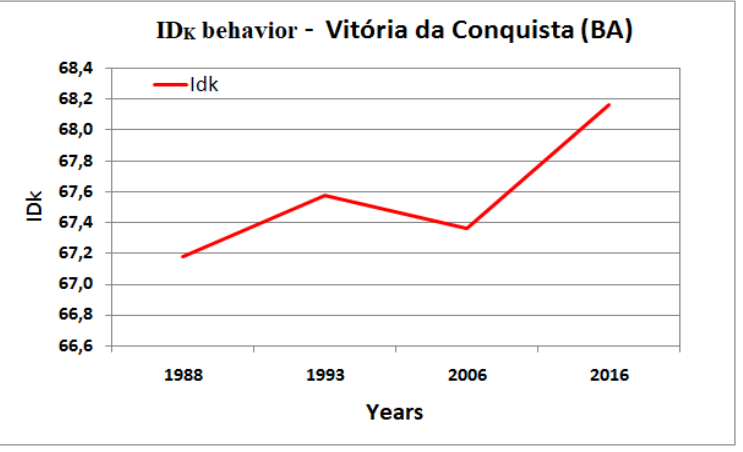

(b)

Figure 17 - Annual averages of temperature (a) and $\mathrm{ID}_{\mathrm{K}}(\mathrm{b})$ of Vitoria da Conquista (BA) for the selected four years.

It is essential that the monitoring of rainfall series is continuous, since as pointed out by Silva et al. (2010) it is important for planning agricultural activities and water resources, in addition to that, changes in climate have influence in everyday life of society, which can cause impacts on social, economic and even cultural activities (Nóbrega et al., 2015). For Santos et al. (2014), climate variability and the frequency of dry and wet extreme events affect on different scales agriculture, water, health and environment.

When observing the months individually (Figure 9) for the rainy season MJJ, all of them represent rainfall downward trend, except for the month of June in Recife, which presents an increase, however it is clear that none of the cases have statistical significance.

\section{Conclusions}

By means of the surface temperature images, higher temperatures were observed in the urban areas of the cities in relation to their surroundings, characterizing the islands of heat. In the case of the Kawamura Discomfort Index $\left(\mathrm{ID}_{\mathrm{K}}\right)$, the highest occurrence identified in the images was thermal comfort, with the exception of 2016, which in all municipalities presented higher values than the images of previous years. The year 2016 showed a very clear predominance, in all cities studied, of discomfort and/or thermal stress due to heat. In none of the cases 
was the occurrence of cold-related discomfort and/or heat stress observed.

The estimates of the mean temperature and the $\mathrm{ID}_{\mathrm{K}}$ of the years whose satellite images, obtained from the observed data, also indicated that the year 2016 was the hottest and most uncomfortable for the urban areas studied.

The use of other satellite imagery indexes, such as the Normalized Difference Built-up Index (NDBI), which is a radiometric index developed to identify urban and built areas, is suggested for future work. The large increase in the spectral response of the built areas between the near infrared and medium infrared bands.

\section{References}

ANSI/ASHRAE. Standard, 1992. Thermal environmental conditions for human occupancy. American Society of Heating, Refrigerating and Air Conditioning Engineers. Atlanta.

Ayra, S.P., 2001. Introduction to Micrometeorology. Academic Press, San Diego.

Baptista, G.M. M. Ilhas Urbanas de Calor. Scientific American Brasil, São Paulo, v. 8, n.08, p. 54-59, 2003.

Baptista, G.M.M., Nascimento, M.E.M., 2016. Geração de cenários de crescimento da mancha urbana da área metropolitana de Brasília por meio da série histórica DMSP-OLS de dados de luz noturna. Revista Brasileira de Cartografia (Online) 68, 911919.

Bertolo, L.S., Rocha, J.V., Young, A.F., 2005. Evolução Temporal do Índice de Vegetação da área Urbana de Curitiba-PR. Simpósio Brasileiro de Sensoriamento Remoto, Goiânia.

Bias, E.S., Baptista, G.M.M., Lombardo, M.A., 2003. Análise do fenômeno de ilhas de calor urbanas, por meio da combinação de dados Landsat e IKONOS. Simpósio Brasileiro de Sensoriamento Remoto, Belo Horizonte.

Campbell, J.B., 1987. Introduction to Remote Sensing. The Guilford Press, New York.

Civerolo, K., Hogrefe, C., Lynn, B., Rosenthal, J., Ku, J.Y., Solecki, W., 2007. Estimating the effects of increased urbanization on surface meteorology and ozone concentrations in the New York City metropolitan region. Atmospheric Environment 41, 1803-1818.

Comarazamy, D.E., Gonzáles, J.E., Luvall, J.C., 2007. The urban heat Island Phenimenon in a Coastal Tropical City: case study of the metropolitan area of San Juan, Puerto Rico. Urbanization, Global
Environmental Change, and Sustainable Development in Latin America 59-75.

Enping Yan., Wang, G., Lin, H., Xia, C., Sun, H., 2015. Phenology-based classification of vegetation cover types in Northeast China using MODIS NDVI and EVI time series. International Journal of Remote Sensing 35, 489-512.

Freitas, E.D., 2003. Circulações locais em São Paulo e sua influência na dispersão de poluentes. Tese (Doutorado). São Paulo, IAG/USP.

Freitas, E.D., Dias, P.L.S., 2005. Alguns efeitos de áreas urbanas na geração de uma ilha de calor. Revista Brasileira de Meteorologia, v. 20, p. 355366,

Freitas, E. D., Rozoff, C. M., Cotton, W. R., Silva Dias, P. L., 2007. Interactions of an urban heat island and sea-breeze circulations during winter over the metropolitan area of São Paulo, Brazil. Boundary-Layer Meteorology 122, 43-65.

Freitas, R.M., Arai, E., Adami, M., Ferreira, A.S., Sato, F.Y., Shimabukur, O.Y.E., Rosa, R.R., Anderson, L.O., Rudorff, B.F.T., 2011. Virtual laboratory of remote sensing time series: visualization of MODIS EVI2 data set over South America. Journal of Computational Interdisciplinary Science 2, 57-68.

Gouvêia, M.L., Freitas, E.D., Branco, F.V., 2006. Estudo do conforto térmico humano na região metropolitana de São Paulo e sua relação com propriedades da superfície urbana. Congresso Brasileiro de Meteorologia, Florianópolis.

Kim, Y., Baik, J., 2004. Spatial and Temporal Structure of the Urban Heat Island in Seoul. Journal of Applied Meteorology 44, 591-605.

Lombardo, M.A., 1985. Ilhas de Calor nas Metrópoles: o exemplo de São Paulo. HUCITEC, São Paulo.

Maia, J.A., 2002. Uma análise do conforto térmico e suas relações meteorotrópicas na cidade de São Paulo. Dissertação (Mestrado). São Paulo, IAG/USP.

Miao, S., Chen, F., Lemore, M. A., Tewari, K., Li, Q., Wang, Y., 2008. An observation and modeling study of characteristics of urban heat island and boundary layer structures in Beijing. Journal of Applied Meteorology and Climatology 48, 484-501.

Nascimento, F.C.A., Araújo, F.R.C.D., Santos, C.A.C., Santos, E.G.S., 2014. Análise das mudanças ambientais provocadas pela expansão urbana na cidade de Mossoró-RN, através do uso de técnicas de Sensoriamento Remoto. Revista Brasileira de Geografia Física 7, 636-642.

Nedel, A.S., 2008. Condições Meteorológicas Favoráveis à Ocorrência de Doenças Respiratórias 
em Crianças da Cidade de São Paulo. Tese (Doutorado). São Paulo, USP.

Ono, H.S.P., Kawamura, T., 1991. Sensible climates in monsoon Asia. International Journal of Biometeorology 35, 39-47.

Peng Gong, J.W., Yu, L., Zhao, Y., Zhao, Y., Liang, L., 2013. Finer resolution observation and monitoring of global land cover: first mapping results with Landsat TM and ETM+ data. International Journal of Remote Sensing 34, 26072654.

Rosa, R., 2009. Introdução ao sensoriamento remoto. 7. ed. EDUFU, Uberlândia.

Sajani, S.Z., Tibaldi, S., Scotto, F., Lauriola, P., 2008. Bioclimatic characterization of an urban area: a case study in Bologna (Italy). Journal of Biometeorology 52, 779-785.

Silva, V.V.B., Kousky, V.E., Silva, F.D.S., Salvador, M.A., Aravequia, J.A., 2013. The 2012 severe drought over northeast Brazil. Bulletin of the
American Meteorological Society 94, 162.

Souza, D.O., Alvala, R.C.S., 2014. Observational evidence of the urban heat island of Manaus City, Brazil. Meteorological Applications 21, 186-193.

Tomlinson, C.J., Chapman, L., Thornesb, J.E., Bakera, C., 2011. Remote sensing land surface temperature for meteorology and climatology: a review. Meteorological Applications 18, 296-306.

Vital, L.A.B., Moreira, E.B.M., Nobrega, R.S., 2012. Estimativa de índice de desconforto humano em um transecto no Município de Olinda/PE. Revista Geonorte, Edição Especial 2, 761-772.

Zhang, Y., Odeh, I.O., Han, C., 2009. Bi-temporal characterization of land surface temperature in relation to impervious surface area, ndvi and ndbi, using a sub-pixel image analysis. International Journal of Applied Earth Observation and Geoinformation 11, $256-264$. 